\title{
THE COUNTER-TERRORIST SYSTEM OF ROMANIA Tomasz BĄK
}

\author{
Wyższa Szkoła Informatyki i Zarządzania w Rzeszowie, Rzeszów, Poland
}

\begin{abstract}
This article presents the counter-terrorist system adopted in Romania. The problem of terrorism is one of the challenges within security issues which the European Union is facing. Only lasting, strong cooperation may lead to combating international terrorism, and one of the countries which attempt to do that is Romania. For such actions to be successful, suitable legal solutions have been implemented and adequate structures and units established with the purpose of fighting terrorism. An enormous role belongs moreover to international cooperation and maintaining good relations between various states within terrorism prevention. The Author focuses in particular on the forms and methods of combating terrorism on various planes.
\end{abstract}

\section{Keywords: European Union, Romania, security, terrorism}

\section{Introduction}

Since the fateful attacks of $11^{\text {th }}$ September 2001 in the USA, and in particular since the terrorist bombing attack in Madrid in March 2004 which killed 191 people, European Union politicians have unanimously spoken for joint international cooperation in combating terrorism. Hypothetically, in the European Union, terrorists can freely move and cross member states' border without much difficulty, particularly within the Schengen system. Considering the global character of such organisations as Al-Qaida [1], it must be taken into account that they may attack at any place in Europe, and at a much larger scale than terrorist organisations active so far in our continent, like ETA [2], IRA [3] or other.

Of course, one needs to be aware that international terrorism is not the only Islamic terrorist groups, remain the major threat for Europe today and in the nearest future.

Joint EU policy requires particular coordination and cooperation in combating terrorism, although it is not a straightforward matter. There is a paradox in the EU's role in counter-terrorism. On challenge for the European Union as concerns security. The member states have been actively participating in peace activities (including security forces training, humanitarian aid, etc.) in Iraq, Afghanistan, the Balkans or in North Africa. They are trying to convince Iran to stop building nuclear weapons. Member state governments are engaged in helping failed states, such as Sudan or Congo, as well as in the issues of cross-border organised crime. In the recent time, it is with great concern that European Union states turn to Ukraine and the unstable situation in that state, with particular consideration for Russia's negative role in that conflict. However, there is no doubt that particularly the attacks in Madrid and in London as well as the more recent one in Paris have clearly shown that terrorism, and especially radical the one hand, the governments agree that co-operation at the EU level is a good thing because of the cross-border nature of the terrorist threat. On the other, they are slow to give the Union the necessary powers (such as investigation and prosecution) and resources (such as spies and money). 
This is because security policy - especially when it concerns citizen protection - goes to the core of national sovereignty, and governments are reluctant to give the EU powers that could interfere with their existing laws and national security practices [4]. The EU is working hard to co-ordinate national counter-terrorism policies, but that requires it at the very start to systemise and consolidate its own counter-terrorist policy at the level of the Union.

Romania attaches great significance to fighting terrorism. It takes all adequate measures to prevent terrorist acts and effectively prosecutes the culprits. In that fight, both human rights and the law are respected. In order to do so, Romania has introduced legal and institutional framework and regulations aiming at fostering international cooperation.

\section{Legal framework}

The most important legal documents concerning terrorism prevention and suppression in Romania are:

- the Strategy of National Security;

- Law No. 51/1991 on the National Security of Romania;

- Law No. 14/1992 on the Organisation and the Operation of the Romanian Intelligence Service;

- Law No. 535/2004 on the Prevention and Suppression of Terrorism;

- National Strategy for the Prevention and Suppression of Terrorism;

- General Protocol on the Organization and Functioning of the National System for Preventing and Suppressing Terrorism;

- National System for Terrorist Alert;

- Regulation on the Organization and Functioning of the Centre for CounterTerrorist Operational Coordination (CCOA);

- Methodology of the organization and execution of counter-terrorism intervention.

One of the major decisions concerning security established the Supreme Council of National Defence (CSAT) in 1990 [5]. The Council's responsibilities covered preparing documents concerning national security of the state. Thanks to Law No. 51 on the national security of $8^{\text {th }}$ July 1991, the concept of national security was precisely defined [6].

Article 3 of the said Law lists threats to Romania's national security, with terrorism being one of them. The Law has also established the rules and regulations of intelligence service activity [7].

For a long time, the Law of 1991 was a document concerning security policy, yet without defining strategic aims. It focused on internal, domestic issues of the state. It allowed to identify the main threats and provide a definition of national security.

On $18^{\text {th }}$ December 2001, the Romanian Parliament passed the Strategy of National Security. The document was developed with a view to Romania's access to NATO [8] and EU structures, as well as multidimensional cooperation in the face of new threats to security, among them terrorist threats and attacks.

Due to the particular attention given to terrorism, the Supreme Council of National Defence approved the National Strategy for the Prevention and Suppression of Terrorism, which allowed to develop the National System for the Prevention and Suppression of Terrorism [9].

The Strategy stresses "the imperative need to put into practice the political commitment of Romania in respect of international terrorism, by taking measures to enhance Romania's contribution to the efforts of preventing and countering terrorism, within bilateral and multilateral cooperation actions."

The Strategy was passed in the year of the attack on WTC, which fact might have been the cause for including there a point concerning international help in fighting terrorism [10]. On EU accession, the Strategy was reformed and improved.

The basic legal provisions on terrorism are contained in Law No. 535/2004 on the Prevention and Suppression of Terrorism, which regulates the National System for the Prevention and Suppression of Terrorism. 
According to the provisions of art. 5 of the Law, "the preventing and combating of terrorism are carried out according to the provisions of international conventions on suppression of terrorism ratified in Romania."

Within the Romanian Intelligence Service (SRI), which is the main body in that field, the Centre for Counter-Terrorist Operative Coordination was established.

Chapter III of the Law regulates measures on preventing the financing of terrorist acts.

Chapter IV covers crimes committed in that matter.

It ought to be mentioned that Law No. 535/2004 abolished Government

Emergency Ordinance No. 141/2001 and Government Emergency Ordinance No. $159 / 2001$, which regulated those issues after the attacks of 9/11 [11].

Law No. 508/2004 established the Department for Investigation of Organised Crime and Terrorism within the Prosecutor's Office of the High Court of Cassation and Justice.

While investigating serious crimes, including acts of terrorism, some special investigation techniques may be used - with observance of fundamental rights and freedoms. Those may include undercover investigators, use of informers, electronic surveillance, monitoring and intercepting communications, or monitoring IT systems. Government Emergency Ordinance No. 21/2004 organises the National System for Management of the State of Emergency. A National Committee for Managing the State of Emergency has been established, led by the Minister of Administration and Internal Affairs and coordinated by the Prime Minister [12].

People who have information related to terrorist acts and who agree to disclose such information to judicial authorities are included in the Witness Protection Programme, according to Law No. $682 / 2002$ on witness protection.

Law No. 211/2004, which entered into force on $1^{\text {st }}$ January 2005, defines measures for compensation and assistance for victims of crimes, including victims of terrorism. Financial compensation is granted by the state through the budget of the Ministry of Justice, based on a decision of a special Commission.

The Romanian strategy of 2006 contained changes, which emphasised the following aims [13]:

- active participation in building international security;

- building a new Euro-Atlantic identity of Romania;

- acting for regional security, assuming the initiatives come mainly from the region's states;

- making Romania to a dynamic security and development vector in the Black Sea area;

- implementing a good governance programme, while maintaining democratic standards and the rule of law;

- building an efficient national economy as the basis for developing the state security system;

- establishing a national integrated system of crisis management (sistem national integrat de management al crizelor) based on a military and a civilian component, at the central and local levels;

- effective protection of critical infrastructure;

- transformation of administrative bodies, government agencies and other public institutions with consideration for security requirements.

The Strategy also described the changes to be introduced in the Romanian army in order to ensure the security of the Romanian state.

2. Structures and units established to fight terrorism

The National System for Preventing and Combating Terrorism (NSPCT) serves to ensure, organise and conduct:

- inter-institutional cooperation, aimed at optimising the fulfilment of tasks;

- competences and prerogatives essential in implementing the national counterterrorist policy, while ensuring that the 
fundamental rights and liberties of citizens are observed.

NSPCT consists of the following public institutions:

- the Romanian Intelligence Service, as a Technical Coordinator;

- the Foreign Intelligence Service, Protection and Security Service, and Special Telecommunication Service;

- Prosecutor's Office within the High Court of Cassation and Justice;

- Ministries responsible for: Internal Affairs and Administrative Reforms, Defence, Foreign Affairs, Agriculture and Rural Area Development, the Environment and Sustainable Development, Transport, Public Health, Communication and IT, Economy and Finance, Justice, and the Department for European Affairs;

- the National Bank of Romania;

- the National Agency for Exports Control;

- the National Office for Preventing and Countering Money Laundering;

- the National Commission for Nuclear Control.

NSPCT bodies develop special activities, individually and/or in cooperation, according to the legal competences they have, in order to prevent and combat any and all terrorist acts and any actions which may cause, encourage or facilitate terrorism, regardless of their means. They organise and conduct activity aimed at obtaining data and information within terrorism suppression both in and outside of the country, in order to prevent, combat and eliminate threats to Romania's national security.

In November 2002, with a decision by the Supreme Council of National Defence (CSAT), the Romanian Intelligence Service (SRI) was appointed the nation's main authority for counter-terrorist activities. In April 2002, the National Strategy for the Prevention and Suppression of Terrorism was approved. Soon after that, CSAT passed the General Protocol on the Organization and Functioning of the National System for Preventing and Suppressing Terrorism (SNPCT), and a bilateral protocol of cooperation between SRI and all SNPCT members was later signed. In April 2004, a decision by CSAT established the National System for Terrorist Alert. It is a mechanism, based on adequate indexes, in the form of a five-level counter-terrorist alert system (a colour system), which indicates the means to be used at each level of terrorist threat

The Supreme Council of National Defence (CSAT) plays a central role in combating terrorism, as it ensures strategic coordination of SNPCT activities.

The Ministry of Internal Affairs and Administration is responsible for coordinating the activities of various police agencies. According to the Government Emergency Ordinance No. 63/2003, their tasks include:

- monitoring the activities of organised crime groups which commit serious crimes, potentially related to terrorist activity;

- determining objects of interest of companies or people who illegally obtain strategic technologies which could be used for terrorist purposes;

- investigating, on request of competent authorities, people suspected of commitment in terrorist activity,

- counteracting and applying sanctions for illegal possession of weapons, ammunition, explosives and dangerous materials or substances which could be used for terrorist purposes.

In February 2005, the Supreme Council of National Defence has approved the Regulation on the Organization and Functioning of the Centre for CounterTerrorist Operational Coordination (ATOCC), functioning within the Romanian Intelligence Service (SRI), which consists of employees of SRI and permanent representatives of the Ministry of Internal Affairs and Administration, the Ministry of National Defence, the Foreign Intelligence Service, and the Protection Service. 
ATOCC is a body functioning within SRI and responsible for:

- exchange of information and operational data concerning terrorism and terrorismrelated activities between public authorities and institutions within SNPCT;

- analysis of the collected data and information to identify and apply the necessary measures [14].

The Centre ensures coherent functioning of the National System for Preventing and Combating Terrorism (SNPCT).

SNPCT members send all information important for preventing and counteracting terrorism to ATOCC, where the analytical department uses such data and information and later outlines the threat assessment. The assessment is then sent to the competent authorities who decide on implementing any necessary measures.

Criminal investigation against terrorismrelated activities is coordinated by a special Directorate for the Investigation of Organised Crimes and Terrorism (DIICOT), established with Law No. 508/2004. While investigating terrorist crimes, DIICOT may request the support of institutions which are members of SNPCT.

The National Office for Preventing and Countering Money Laundering is responsible for blocking any financing sources of terrorist organisations. The Office receives all necessary information concerning suspicious financial transactions and may notify the Prosecutor's Office of the High Court of Cassation and Justice, which may suspend the particular transaction.

The Romanian Armed Forces - Fortele Armate Romane - consist of land forces, air force and the navy.

The Armed Forces come under the Ministry of Defence, and in the case of war the President takes control over them [15].

Beside the Armed Forces, Romania also has military services not included in the Army [16]:

- Gendarmerie

- Inspectorate for Emergency Situations
- General Directorate of Defence Information:

$\checkmark \quad$ Directorate of Military Intelligence

$\checkmark$ Directorate of Military Security

- Romanian Special Telecommunications Service

Within the International Security Assistance Force, Romania takes part in the mission in Afghanistan.

Rescuing hostages and combating terrorism are the responsibility of civilian special forces, which include a rapid reaction gendarmerie company [17].

The Romanian counter-terrorist unit SIIAS - the Independent Special Interventions and Actions Service (Serviciul Independent de Interventii si Actiuni Specjale) - is an elite unit under the command of the Romanian Police. The unit incorporates the best combatants from all the country's rapid intervention formations [18].

The unit consists of 3 detachments of 30 men each, located in Bucharest. It was created in 1995, from a core of specialists from the Police Organized Crime Task Force. The unit performs the most dangerous operations and is responsible for special police duty across the country. SIIAS is a special forces unit under the Ministry of the Interior.

The unit's main tasks are:

- arresting the most dangerous criminals;

- intervening in cases of

- armed robberies;

- vehicle hijacking;

- hostage taking;

- VIP protection.

SIIAS is a unit with both fighters and civilian employees [19].

\section{International cooperation concerning counteracting terrorism}

According to the provisions of the National Strategy for Preventing and Combating Terrorism, one of the state's aims is to take part in all the international efforts aimed at preventing and combating terrorism in different geographical areas, by such activities as:

- active contribution to bi- and multilateral initiatives meant to determine the most 
efficient political and diplomatic actions, regulations and other legal documents, as well as international cooperation mechanisms meant to prevent the development of terrorist acts and associated activities;

- integrating the responsibilities assumed under international agreements into the national legal framework and activities supported by Romania;

- information exchange;

- involvement of professional armed forces in international military operations, according to UN Resolutions.

Romania has ratified the international conventions and agreements on preventing and combating terrorism. The state has ratified all UN Conventions related to that matter [20].

The following treaties have been ratified or are subject to an accession under the aegis of the United Nations Organisation:

- Convention on Offences and Certain Other Acts Committed On Board Aircraft ("Tokyo Convention", 1963 aviation safety);

- Convention for the Suppression of Unlawful Seizure of Aircraft ("Hague Convention", 1970 - aircraft hijacking, ratified by Romania in 1972, Regulation No. 143/1972);

- Convention for the Suppression of Unlawful Acts against the Safety of Civil Aviation ("Montreal Convention", 1971 - on acts of aviation sabotage, such as attacks aboard aircraft in flight);

- Convention on the Prevention and Punishment of Crimes Against Internationally Protected Persons (1973 - attacks on senior government officials and diplomats);

- International Convention against the Taking of Hostages (1979; Romania acceded to it in 1990 - Ordinance No. 111/1990);

- Convention on the Physical Protection of Nuclear Material (1980 - against unlawful gaining and use of nuclear materials);
- Protocol for the Suppression of Unlawful Acts of Violence at Airports Serving International Civil Aviation, supplementary to the Convention for the Suppression of Unlawful Acts against the Safety of Civil Aviation (1988 - it extends and supplements the Montreal Convention;

- Convention for the Suppression of Unlawful Acts against the Safety of Maritime Navigation (1988 - concerns terrorist activities on ships);

- Protocol for the Suppression of Unlawful Acts against the Safety of Fixed Platforms Located on the Continental Shelf (1988);

- Convention on the Marking of Plastic Explosives for the Purpose of Detection (1991 - it provides for marking to facilitate detection of plastic explosives to fight e.g. aircraft sabotage);

- International Convention for the Suppression of Terrorist Bombing (1997);

- International Convention for the Suppression of the Financing of Terrorism (1999);

- Protocol to Prevent, Suppress and Punish Trafficking in Persons, New York, 2000;

- Protocol against the Smuggling of Migrants by Land, Sea and Air, New York, 2000;

- International Convention for the Suppression of Acts of Nuclear Terrorism, New York, $14^{\text {th }}$ September 2005.

Law No. 302/2004 on international judicial cooperation in criminal matters complies with the requirements of the Security Council Resolution No. 1373 (2001). And so extradition for terrorist offences cannot be denied due to political motivation. The law also allows extradition of Romanian citizens from Romania, under certain conditions.

Romania has also ratified the European Convention on the Suppression of Terrorism and the Amending Protocol thereto. 
On $16^{\text {th }}$ May 2005, Romania became one of the first 31 states which in Warsaw signed the Council of Europe Convention on Laundering, Search, Seizure and Confiscation of the Proceeds from Crime and on the Financing of Terrorism.

The Convention on Laundering, Search, Seizure and Confiscation of the Proceeds from Crime and on the Financing of Terrorism was ratified with Law No. 420/2006.

As a European Union member state, Romania has implemented EU instruments, including the European Arrest Warrant Framework Decision, the Mutual Legal Assistance Convention of 2000 and its Protocol of 2001, the Schengen legislation.

Also as a European Union member state, Romania has taken part in negotiations on the Framework Decision which is to update the current Framework Decision on combating terrorism and to align it with the Council of Europe Convention on the Prevention of Terrorism. That includes new references to the following:

- public encouragement to commit terrorist offences;

- recruiting for terrorist purposes;

- training terrorists.

The Regional Centre for Combating TransBorder Crime (SECI), established in Romania within the South-East European Initiative, conducts training on law enforcement and exchange of intelligence in order to counteract cross-border crime, including terrorism, in 12 countries of Central and Eastern Europe. Romania is also part of the Black Sea Economic Cooperation Agreement.

Romania has concluded bilateral agreements on combating organised crime and terrorism with most European states and with some countries in other geographical areas.

Another document concerning the suppression of terrorism is the Agreement between the Government of the Republic of Poland and the Government of Romania on Cooperation in Combating Organized Criminality and Terrorism of $11^{\text {th }}$ July
2001. It was concluded to ensure mutual help and fostering contacts between the two states [21].

\section{Forms and methods of fighting terrorism}

Fighting terrorism effectively requires a modern, flexible and multi-tasking security system. The efforts to improve security and combat terrorism in Romania include the following:

- effective intelligence and counterintelligence forces;

- more agile security forces and increased information exchange, coordination and cooperation;

- improved operational and investigation methods to find and eliminate every person who is logistically and operationally involved in financing or support for terrorist activities;

- rapid intervention to allow capturing terrorists, freeing hostages, restoring order;

- better guard and society protection, as well as help for victims of attacks.

The fight against terrorism in Romania is not the task of one agency, but rather the result of the joint activities of many institutions concerned with security.

Romania has introduced many methods aimed at combating terrorism, e.g.:

- planning, organisation and performance of all activities within prevention;

- activities and measures taken within the country in order to find and destroy terrorists;

- gathering and analysing all threats to security, including the threat of terrorism.

Seminars, meetings, visits in education facilities are organised in order to educate the Romanian society. Such efforts have been undertaken by intelligence forces. Due to that, the citizens have not only become more aware of terrorist threats at the national, regional and international level, but they have also become more willing to notify security institutions on threats. It is noticeable that much of the information that contributes to preventing and combating 
terrorist threats in Romania has come from the Romanian society [22].

The Romanian police has bought a new Israeli-produced biometric identification system. The ADIS system, also named the Printak Biometric Identification Solution, allows for searching many databases at the same time and has advanced facial identification devices. The system will be used by Romanian investigative staff and police. There are also plans for it to be used by the Ministry of Internal Affairs, the National Office for Refugees and the Border Police.

The forms and methods of combating terrorism in Romania comply with the principles applied at EU level.

\section{Conclusion}

The terrorist attacks in the USA on $11^{\text {th }}$ September 2001, and perhaps mainly the attacks in Madrid and London as well as in Paris, have made European Union and its members, including Romania, aware of how important it is to have the necessary strategy and legal framework, to develop a unified system of action in case of such an attack, and to develop close international cooperation between particular countries. The strategy of action should among others cover such ventures as [23]:

- prevention, by creating legal framework and adequate structures for preventing and combating terrorism in the member states, gathering and analysing data, assessing the danger and cooperating with international institutions concerned with fighting terrorism;

- protection of citizens and important strategic objects against a potential terrorist attack. This requires naming the potential targets of terrorist attacks and finding sufficient standards for their protection, including the legal framework;

- reaction, i.e. taking actions aimed at effective crisis management and minimising the effects of an attack, as well as assistance to victims of the attack;
- prosecution, including all activities of competent services aimed at defeating the potential attackers, blocking their ability to act, and quickly bringing them to justice.

Hence to appropriately prepare for a terrorist attack occurring it must be assumed that the European Union, including Romania, is in danger of a terrorist attack and that it is not sufficiently prepared not only to detect plans of such an attack, but also to cope with its results. Moreover, a change must be enforced in the mentality of decision-makers and the competent services, who have many times assured publicly that the situation is different despite the facts saying something else. In that connection, several important actions should be taken, such as [24]:

- developing adequate strategies and legal framework both at the level of the European Union as an organisation and in all its 28 member states (including Romania);

- developing in each state adequate structures to prevent and combat terrorism, including the formation of a unified structure to coordinate gathering intelligence data concerning terrorists from all services and to prepare reports on terrorist threats for the most important people and institutions in the state;

- suitable action procedures in case of terrorist threat must be created, including legal bases for their application, as well as suitable tactic procedures;

- developing a system for information exchange and operation coordination between particular member states, as well as with the countries which are leading in the field of fighting terrorism and have the greatest fighting experience, including also joint training ventures;

- it is necessary to prepare counterterrorist forces to act in contamination conditions or under threat of contamination (detaining people who have dangerous substances), as well as to prepare rescue 
and medical infrastructure (network of hospitals prepared to hospitalise victims of mass destruction weapons, wellprepared rescue services, including contamination clean-up parties);

- effective crisis management structures must be developed, with a clear division of competences and responsibilities, responsible mainly for coordination and cooperation between particular services (police, army, rescue services, central and local government organs);

- it is necessary to undertake a range of training ventures, conducted in the most realistic manner, which would coordinate particular structures in action;

- it is essential to have Union-wide and national educational and informational campaigns to provide the society with knowledge on the threats and on conduct in a crisis.
Another important factor - in my view the most important one - is social awareness. It is still commonly believed that since we are living in Europe, we are in no way in danger, and especially not in danger of terrorist attacks. That could not be further from the truth. Of course, this is not about terrorising societies and spreading a sense of danger. It is about preparing the society for joint counteraction of such attacks, for the ability to specify the threats, and suitable reaction if someone is in the area of an attack.

To sum it up, it must be stated that the European Union - and thus also Romania is to a large degree in danger of terrorist attacks. The increase of security in that scope depends on joint actions of EU and national institutions and the whole society. Sensitivity to any signals may prevent acts of terror and raise state security level.

\section{References}

[1] Al-Qaida - terrorist organisation established 1988 by Abdallah Azzam. It supports extremist Islamic groups across the world

[2] ETA - separatist organisation fighting for an independent Basque Country (Spain, France)

[3] IRA - organisation active in Northern Ireland, aiming at releasing that territory from under British rule and including it in the Republic of Ireland. Since 1920 in the underground after the defeat in 1916 (Easter Rising). Under the Good Friday Agreement of 1998 IRA limited its activity. The organisation is responsible for the death of about 3000 people. On $28^{\text {th }}$ July 2005 it declared the actual end of its activity, http://www.wos.net.pl/terroryzm-organizacje-terrorystyczne.html [10.02.2015]

[4] Daniel Keohane, The EU and counter-terrorism, working paper, p. 3, Centre for European Reform, 2005 - http://library.coleurope.eu/pdf/CER/keohane.pdf [10.02.2015]

[5] Law No. 39 of $13^{\text {th }}$ December 1990 on Setting Up, Organization and Functioning of the Supreme Council of National Defence

[6] Law No. 51 on the National Security of Romania of $8^{\text {th }}$ July 1991, art. 1

[7] Law of $8^{\text {th }}$ July 1991, art. 8-16

[8] Introduction to the Strategy of National Security of Romania of $18^{\text {th }}$ December 2001

[9]http://www.coe.int/t/dlapil/codexter/Source/country_profiles/CODEXTER\%20Profile\%20 $\% 282008 \% 29 \% 20$ Romania.pdf [10.02.2015]

[10] Strategy of National Security of Romania, p. 13

[11] http://www.coe.int/t/dlapil/codexter/ Source/country_profiles/CODEXTER\%20Profile\%20\%282008\%29\%20Romania.pdf [10.02.2015]

[12] Ibid

[13] Strategy of National Security of Romania of 2006

[14] Fusion Centres Throughout Europe. All-Source Threat Assessments in the Fight Against Terrorism, Belgian Standing Intelligence Agencies Review Committee, Intersentia 2010, Antwerp-Oxford-Portland, p. 180 
[15] http://myvimu.com/collection/47788134?from=rss,[10.02.2015]

[16] http://edu.gazeta.pl/edu/h/Rumu\%C5\%84skie+Si\%C5\%82y+Zbrojne, [10.02.2015]

[17] B. Hołyst "Terroryzm" (Terrorism) vol.2, LexisNexis 2009, p. 1604

[18] www.romanianspecialforces.com/siias.html, [10.02.2015]

[19] K. Jałoszyński, Jednostka kontrterrorystyczna - element działań bojowych w systemie bezpieczeństwa antyterrorystycznego (A Counter-Terrorist Unit as an Element of Military Actions Within an Anti-Terrorist Security System), WSPol., Szczytno 2011, p. 224

[20] Late September 2005, Romania signed the $13^{\text {th }}$ UN Convention in that matter - the Convention on the Suppression of Acts of Nuclear Terrorism. The said UN Convention was ratified by Law 369/2006

[21] Polish Journal of Laws of 2004, No. 154 item 1625

[22] http://journal.dresmara.ro/issues/volume3_issue1/04_matei.pdf [10.02.2015]

[23] Interview with the Head of the Mazowieckie Region Crisis Management Department, Zenon Sobejko

[24] M. Piekarski, Polska - czy jesteśmy bezpieczni? (Poland - Are We Safe?), at: http://www.specops.pl/vortal/taktyka_czarna/walka_z_terrorem/Michal_Piekarski/Polska _czy_jestesmy_bezpieczni/polska_czy_jestesmy_bezpieczni.htm, 2010 [10.02.2015] 